\title{
A CORRELATION OF CLINICAL AND HEMODYNAMIC STUDIES \\ IN PATIENTS WITH HYPERTHYROIDISM WITH AND WITHOUT CONGESTIVE HEART FAILURE *
}

\author{
By JOHN S. GRAETTINGER, JOSEPH J. MUENSTER, $†$ LOUIS A. SELVERSTONE $\ddagger$ \\ AND JAMES A. CAMPBELL \\ (From the Cardio-Respiratory Division, Department of Medicine, Presbyterian Hospital, and \\ Department of Medicine, University of Illinois College of Medicine, Chicago, Ill.)
}

(Submitted for publication February 2, 1959; accepted April 2, 1959)

The occurrence of congestive heart failure during the course of hyperthyroidism has frequently been observed, as has its amelioration after reestablishment of the euthyroid state. The majority of patients in whom congestive failure has appeared have been believed to have myocardial disease of other etiology $(1,2)$, but the probability that the circulatory load imposed by hyperthyroidism can cause even the otherwise healthy heart to fail has also been suggested (3-5). During investigation of the hemodynamic consequences of the endogenous circulatory loads imposed by various disorders, we have obtained clinical and physiologic data in 20 patients with hyperthyroidism, seven of whom were or had been in congestive heart failure. At the time of study we were unable to determine whether the congestive failure was principally attributable to myocardial damage antedating thyrotoxicosis, to a possibly direct toxic action of thyroxin on the myocardium, or might be due to the circulatory load imposed by this disease overcoming the reserve of an otherwise healthy myocardium. Evaluation of these patients after they had become euthyroid disclosed that only five had residual heart disease. The measurements made in these patients with congestive failure differed significantly from those obtained in hyperthyroid patients not in failure; furthermore, the patients in whom congestive failure had occurred could be subdivided into two significantly different groups on the basis of the hemodynamic data. It is our purpose in the present paper to

* This work was supported in part by a grant from the United States Public Health Service (U.S.P.H.S. H404) and in part by a grant from the Otho S. A. Sprague Memorial Institute.

$\dagger$ This work was done during the tenure of a James $B$. Herrick Fellowship in Cardiology.

¥ Present address : New England Center Hospital, Boston, Mass. contrast the physiologic aberrations in hyperthyroidism uncomplicated by congestive failure with the abnormalities found in patients in whom hyperthyroidism and congestive heart failure coexist with or without antecedent heart disease.

\section{CLINICAL MATERIAL}

Hemodynamic data obtained in 21 studies performed in 20 patients with hyperthyroidism form the basis of this report. Each patient had had symptoms and signs of thyrotoxicosis for more than three months. The patients were divided into two major groups shown in Table I on the basis of the presence or absence of congestive heart failure on clinical examination during the course of their illness prior to physiologic study.

Group I consists of 14 patients who had not manifested congestive failure. Eight of these 14 patients had no evidence of cardiorespiratory disease and comprise Group IA. The other six patients had evidence of heart disease and comprise Group IB. The average age of the eight Group IA patients was 34 , with a range of 24 to 52 , years. Exertional fatigue and breathlessness were noted by seven of these eight patients but resulted in slight or no limitation in exercise tolerance. Their physical examinations were unremarkable except for typical evidence of hyperthyroidism. Grade I or II upper left sternal border systolic murmurs were noted in three, and Grade I apical systolic murmurs in two, of these patients. Teleroentgenograms in these patients revealed normal cardiac size and contour in six and slight prominence of the right ventricular outflow tract in two (E. M., M. H.). Electrocardiograms in five showed sinus tachycardia and in two normal sinus rhythm. Increased QRS voltage was noted in the unipolar precordial leads of six of the eight (maximum $\mathrm{S}$ wave plus maximum $\mathrm{R}$ wave over $40 \mathrm{~mm}$.). Total blood volume estimated with $\mathrm{I}^{131}$ and related to presenting body weight was normal in each of the three in whom this measurement was made (E. M., G. C., M. H.).

The other six patients with thyrotoxicosis uncomplicated by congestive failure but with definite evidence of heart disease are designated Group IB. The average age of these patients was 47 years, with a range of 28 to 56 . Four had hypertensive heart disease (J. J., M. R., F. S., M. He.) with long-standing diastolic hypertension, ab- 
normal retinal arterioles and left ventricular hypertrophy by electrocardiographic and roentgenographic examination. Another patient (L. D.), aged 37, had moderate cardiac enlargement with electrocardiographic evidence of increased QRS voltage and changes suggestive of diffuse injury and ischemia which evolved to normal during the initial month of therapy for her hyperthyroidism. The final patient (L. P.) had rheumatic heart disease with mitral regurgitation; her electrocardiogram was compatible with left atrial and ventricular hypertrophy as were her roentgenographic studies.

Despite the evidence of hyperthyroidism and heart disease in each patient no evidence of congestive failure was found. Although abnormalities of the cardiac silhouette were present in teleroentgenograms in each of the patients, in no instance was evidence of pulmonary congestion noted. Electrocardiograms in five of the six disclosed a sinus mechanism and atrial fibrillation was present in one (F. S.) at the time of study. Transient atrial fibrillation during hospitalization had occurred, however, in three of the other five (J. J., M. R., L. P.). Arm to lung circulation times ranged from 11 to 17 seconds in the four patients in whom this determination was made. Total blood volumes were within normal limits in two patients (F. S., L. D.) and increased by 30 per cent in one (L. P.). One of the patients (M. R.) had a significant anemia.

Group II consists of seven other patients with hyperthyroidism, in each of whom congestive heart failure had occurred during the course of the disease. They are separated into two groups by the levels of their cardiac outputs.

Group IIA consists of four patients with normal cardiac outputs :

M. He. was a 68 year old female with hyperthyroidism and hypertensive heart disease who had been studied previously (Group IB). She had not become euthyroid. A year after the first study she entered the hospital in moderately severe congestive failure which had cleared by the time of her second study.

N. S. was a 42 year old female who presented with evidence of rheumatic heart disease with mitral and aortic regurgitation, atrial fibrillation and congestive failure. Following physiologic studies she responded well to antithyroid medication and her congestive failure cleared.

S. S. ${ }^{1}$ was a 36 year old male who rapidly developed severe congestive failure in the week prior to admission. On examination he presented marked pulmonary and peripheral edema, a Grade III apical holosystolic murmur, atrial fibrillation, and in teleroentgenograms had diffuse cardiac enlargement with pulmonary congestion. He lost 40 pounds in a week with improvement in the signs of congestive failure, but cardiac enlargement and pulmonary congestion persisted in his chest films at the time of study. It was felt that he probably had antecedent rheumatic heart disease. He was treated with $\mathrm{I}^{121}$. Two years

${ }_{1}^{1}$ This patient was studied through the courtesy of Dr. Lyle A. Baker, Chief of Medicine, Veterans Administration Hospital, Hines, Ill. after study he was entirely well; the cardiac examination and teleroentgenograms were normal and electrocardiograms revealed that he had reverted to normal sinus rhythm.

H. K. was a 55 year old female who presented evidence of hypertensive cardiovascular disease with congestive failure in addition to hyperthyroidism. Atrial fibrillation was present. Teleroentgenograms disclosed diffuse cardiac enlargement and congestion of the lung fields. Six months later following antithyroid therapy her thyrotoxicosis and congestive failure were much improved.

Group IIB consists of three patients who had unusually high cardiac outputs :

G. F. ${ }^{2}$ was a 38 year old male in whom a diagnosis of hyperthyroidism was made two years prior to study. Various antithyroid drugs had been given until a few weeks prior to admission. In the five months prior to observation, dyspnea and edema appeared and progressed despite digitalis and diuretic therapy. Examination revealed severe congestive failure. Teleroentgenograms showed diffuse cardiac enlargement with pulmonary congestion; an electrocardiogram showed atrial fibrillation at a rate of 124 without other abnormality. Physiologic studies were performed eight days following admission at which time his hemoglobin had fallen to $8.3 \mathrm{Gm}$. Two and one-half years later his functional capacity was Class $I$ and a teleroentgenogram showed normal heart size and contour; atrial fibrillation persisted without other electrocardiographic abnormality. His hemoglobin was normal.

P. R. was a 49 year old female who presented with severe congestive failure. An electrocardiogram showed atrial fibrillation at a rate of 245 with runs of ventricular tachycardia. Blood volume was 35 per cent above predicted. A teleroentgenogram was interpreted as normal. She was treated with oxygen, morphine, Lugol's solution and propylthiouracil and rapidly digitalized. Physiologic studies were performed 19 days after admission, at which time her neck veins were not distended and her lung fields were clear. Serial electrocardiograms showed progressive decrease in ventricular rate with persistence of fibrillation and nonspecifically abnormal ST-T deflections. She was readmitted nine months later because of recurrence of dyspnea, orthopnea and edema. Her heart was enlarged; atrial fibrillation and $3+$ edema were present. Her basal metabolic rate was +47 per cent. A thyroidectomy was performed followed by remission of symptoms and signs of heart disease despite the persistence of atrial fibrillation for the six month follow-up period available.

I. J. was a 28 year old female who presented with a history of hyperthyroidism of 22 months' duration and congestive failure of six months' duration with known hypertensive heart disease. An electrocardiogram showed normal sinus rhythm and was compatible with left ventricular hypertrophy. After physiologic studies she

2 This patient was studied through the courtesy of Dr. Lyle A. Baker, Chief of Medicine, Veterans Administration Hospital, Hines, Ill. 
TABLE I

Hemodynamic data in patients with thyrotoxicosis

\begin{tabular}{|c|c|c|c|c|c|c|c|c|c|c|c|c|c|c|c|}
\hline \multirow[b]{2}{*}{ Patient } & \multirow[b]{2}{*}{ Age } & \multirow[b]{2}{*}{ Sex } & \multirow{2}{*}{$\begin{array}{l}\text { Surface } \\
\text { area }\end{array}$} & \multirow{2}{*}{$\begin{array}{l}\text { Hemo- } \\
\text { globin }\end{array}$} & \multirow{2}{*}{$\begin{array}{l}\text { Basal } \\
\text { meta- } \\
\text { bolic } \\
\text { rate }\end{array}$} & \multicolumn{2}{|c|}{$\begin{array}{c}\text { Oxygen } \\
\text { consumption }\end{array}$} & \multicolumn{2}{|c|}{$\begin{array}{c}\text { Cardiac } \\
\text { index }\end{array}$} & \multicolumn{2}{|c|}{$\frac{\underset{(L . / m i n .}{\text { Cardiac output } 100)}}{\underset{(m l .)}{\text { Oxygen consumption }}}$} & \multicolumn{2}{|c|}{$\begin{array}{c}\text { Stroke } \\
\text { index }\end{array}$} & \multicolumn{2}{|c|}{$\begin{array}{c}\text { Heart } \\
\text { rate }\end{array}$} \\
\hline & & & & & & $\mathbf{R}$ & $\mathbf{E}$ & $\mathbf{R}$ & $\mathbf{E}$ & $\mathbf{R}$ & $\mathbf{E}$ & $\mathbf{R}$ & $\mathbf{E}$ & $\mathbf{R}$ & $\mathbf{E}$ \\
\hline & & & $M .^{2}$ & $G m$. & & \multicolumn{2}{|c|}{$\operatorname{ml.} / \min . / M .^{2}$} & \multicolumn{2}{|c|}{$L . / \min . / M .2$} & & & \multicolumn{2}{|c|}{$\begin{array}{c}\text { ml.jbeatl } \\
M .2\end{array}$} & \multicolumn{2}{|c|}{$\begin{array}{l}\text { beats/ } \\
\text { minute }\end{array}$} \\
\hline \multicolumn{16}{|c|}{ A. No heart disease (8) } \\
\hline J. A. . & 27 & $\mathbf{F}$ & 1.75 & 11.6 & $\begin{array}{l}+51 \\
+42\end{array}$ & 174 & 283 & 4.54 & 5.42 & 2.61 & 1.92 & 44 & 48 & 103 & 112 \\
\hline S. P. & 57 & $\mathbf{F}$ & 1.26 & 13.2 & $\begin{array}{l}+34^{*} \\
+46\end{array}$ & 168 & 298 & 5.20 & 6.42 & 3.10 & 2.15 & 41 & 46 & 128 & 140 \\
\hline G. C. & 24 & $\mathbf{F}$ & 1.63 & 12.0 & $\begin{array}{r}+49 \\
+49\end{array}$ & 187 & 272 & 6.64 & 9.53 & 3.55 & 3.50 & 63 & 75 & 104 & 127 \\
\hline E. M. & 29 & $\mathbf{F}$ & 1.62 & 12.5 & $\begin{array}{l}+55^{*} \\
+53\end{array}$ & 194 & 425 & 6.27 & 8.49 & 3.23 & 2.00 & 48 & 57 & 132 & 150 \\
\hline M. H. & 30 & $\mathbf{F}$ & 1.50 & 10.7 & $\begin{array}{l}+23 * \\
+62\end{array}$ & 201 & 267 & 5.95 & 5.91 & 2.96 & 2.21 & 60 & 57 & 99 & 103 \\
\hline R. E. & 52 & $\mathbf{M}$ & 1.79 & 12.8 & $\begin{array}{l}+60^{*} \\
+68\end{array}$ & 211 & 344 & 5.55 & 8.00 & 2.63 & 2.33 & 50 & 67 & 110 & 120 \\
\hline B. $\mathbf{R}$. & 24 & $\mathbf{M}$ & 1.72 & 12.3 & $\begin{array}{l}+85 \\
+81\end{array}$ & 252 & 395 & 7.44 & 14.26 & 2.95 & 3.61 & 66 & 116 & 113 & 123 \\
\hline E. A. & 32 & $\mathbf{F}$ & 1.66 & 12.7 & $\begin{array}{r}+33 \\
+83\end{array}$ & 225 & 381 & 6.25 & 7.76 & 2.78 & 2.04 & 73 & 75 & 86 & 103 \\
\hline $\begin{array}{l}\text { Mean } \\
\text { Standard }\end{array}$ & $\begin{array}{c}34 \\
\text { error }\end{array}$ & & 1.62 & 12.2 & +61 & $\begin{array}{r}202 \\
10\end{array}$ & $\begin{array}{c}333 \dagger \\
22\end{array}$ & $\begin{array}{l}5.98 \\
0.32\end{array}$ & $\begin{array}{l}8.22 \dagger \\
0.99\end{array}$ & $\begin{array}{l}2.98 \\
0.11\end{array}$ & $\begin{array}{l}2.47 \dagger \\
0.24\end{array}$ & $\begin{array}{r}56 \\
4\end{array}$ & $\begin{array}{r}68 \\
8\end{array}$ & $\begin{array}{r}109 \\
5\end{array}$ & ${ }_{6}^{122 \dagger}$ \\
\hline \multicolumn{16}{|c|}{ B. Heart disease (6) } \\
\hline J. J.8 & 56 & $\mathbf{M}$ & 1.73 & 13.6 & $\begin{array}{l}+38 \\
+31\end{array}$ & 164 & 347 & 2.90 & 5.47 & 1.77 & 1.58 & 40 & 66 & $71 \|$ & 83 \\
\hline M. R. & 46 & $\mathbf{F}$ & 1.90 & 9.5 & $\begin{array}{l}+53 * \\
+41\end{array}$ & 172 & 249 & 4.77 & 5.13 & 2.77 & 2.06 & 49 & 51 & $98 \|$ & 100 \\
\hline F. S. & 46 & $\mathbf{M}$ & 1.74 & 14.7 & $\begin{array}{l}+36 * \\
+41\end{array}$ & 183 & 312 & 2.84 & 3.68 & 1.55 & 1.18 & 24 & 23 & 120 ป & 160 \\
\hline L. D. & 37 & $\mathbf{F}$ & 1.62 & 11.8 & $\begin{array}{l}+35 \\
+47\end{array}$ & 181 & 348 & 4.58 & 6.00 & 2.53 & 1.72 & 52 & 63 & 87 & 95 \\
\hline L. P. & 28 & $\mathbf{F}$ & 1.51 & 14.1 & $\begin{array}{l}+74^{*} \\
+75\end{array}$ & 205 & 411 & 5.08 & 8.43 & 2.48 & 2.05 & 53 & 70 & $95 \|$ & 120 \\
\hline M. He. & 66 & F & 1.43 & 13.3 & $\begin{array}{l}+45 \\
+86\end{array}$ & 208 & 403 & 6.31 & 6.40 & 3.03 & 1.59 & 55 & 49 & 116 & 132 \\
\hline $\begin{array}{l}\text { Mean } \\
\text { Standard }\end{array}$ & $\begin{array}{l}47 \\
\text { error }\end{array}$ & & 1.66 & 12.8 & +54 & $\begin{array}{r}185 \\
7\end{array}$ & $\underset{25}{345 \dagger}$ & $\begin{array}{l}4.41 \\
0.55\end{array}$ & $\begin{array}{l}5.85 \dagger \\
0.64\end{array}$ & $\begin{array}{l}2.36 \\
0.27\end{array}$ & $\begin{array}{l}1.70 \dagger \\
0.14\end{array}$ & $\begin{array}{r}46 \\
5\end{array}$ & $\begin{array}{r}54 \\
7\end{array}$ & $\begin{array}{r}98 \\
7\end{array}$ & $\begin{array}{c}115 \dagger \\
11\end{array}$ \\
\hline \multicolumn{16}{|c|}{ Group II-Congestive failure } \\
\hline \multicolumn{16}{|c|}{ A. Normal cardiac output (4) } \\
\hline M. He. & 68 & $\mathbf{F}$ & 1.46 & 13.1 & $\begin{array}{l}+26 * \\
+21\end{array}$ & 147 & 207 & 2.51 & 2.89 & 1.71 & 1.40 & 28 & 27 & 89 & 107 \\
\hline N.S. & 42 & $\mathbf{F}$ & 1.78 & 9.6 & $\begin{array}{l}+29 * \\
+49\end{array}$ & 175 & 371 & 4.45 & 4.91 & 2.54 & 1.32 & 45 & 35 & 100 ป & 140 \\
\hline H. K. & 55 & F & 1.65 & 12.3 & $\begin{array}{l}+45^{*} \\
+96\end{array}$ & 225 & 262 & 3.31 & 3.67 & 1.47 & 1.40 & 30 & 31 & 110 ๆ & 119 \\
\hline S. S.8 & 36 & $\mathbf{M}$ & 1.24 & 13.5 & $\begin{array}{l}+54^{*} \\
+54\end{array}$ & 206 & 263 & 3.12 & 3.83 & 1.51 & 1.46 & 25 & 31 & 125 ป & 125 \\
\hline $\begin{array}{l}\text { Mean } \\
\text { Standard }\end{array}$ & $\begin{array}{c}50 \\
\text { error }\end{array}$ & & 1.53 & 12.1 & +55 & $\begin{array}{r}188 \\
17\end{array}$ & $\underset{34}{276 \dagger}$ & $\begin{array}{l}3.35 \\
0.41\end{array}$ & $\begin{array}{l}3.83 \\
0.42\end{array}$ & $\begin{array}{l}1.81 \\
0.25\end{array}$ & $\begin{array}{l}1.40 \\
0.03\end{array}$ & $\begin{array}{r}32 \\
4\end{array}$ & $\begin{array}{r}31 \\
2\end{array}$ & $\begin{array}{r}106 \\
8\end{array}$ & $\begin{array}{r}123 \\
7\end{array}$ \\
\hline \multicolumn{16}{|c|}{ B. High cardiac output (3) } \\
\hline G. F.8 & 38 & $\mathbf{M}$ & 1.94 & 8.3 & $\begin{array}{l}+25^{*} \\
+24\end{array}$ & 166 & 273 & 8.26 & 7.10 & 4.98 & 2.60 & 66 & 45 & 124ป & 156 \\
\hline P. $\mathbf{R} .8$ & 49 & $\mathbf{F}$ & 1.52 & 11.6 & $\begin{array}{l}+71 \\
+70\end{array}$ & 205 & 249 & $\mathbf{8 . 5 0}$ & 6.68 & 4.15 & 2.68 & 65 & 39 & $129 \pi$ & 173 \\
\hline I. J. & 28 & $\mathbf{F}$ & 1.96 & 11.2 & $\begin{array}{r}+25 \\
+110\end{array}$ & 259 & 297 & 10.04 & 8.91 & 3.88 & 3.00 & 90 & 70 & 111 & 127 \\
\hline $\begin{array}{l}\text { Mean } \\
\text { Standard }\end{array}$ & $\begin{array}{l}38 \\
\text { error }\end{array}$ & & 1.81 & 10.3 & +68 & $\begin{array}{r}210 \\
27\end{array}$ & $\begin{array}{r}273 \\
14\end{array}$ & $\begin{array}{l}8.93 \\
0.56\end{array}$ & $\begin{array}{l}7.56 \dagger \\
0.68\end{array}$ & $\begin{array}{l}4.34 \\
0.33\end{array}$ & $\begin{array}{l}2.76 \\
0.12\end{array}$ & $\begin{array}{r}73 \\
8\end{array}$ & $51 \ddagger$ & 121 & $\begin{array}{r}152 \\
13\end{array}$ \\
\hline $\begin{array}{l}\text { Normals } \\
\text { Mean } \\
\text { Standard }\end{array}$ & $\begin{array}{l}\text { (6) } \\
36 \\
\text { error }\end{array}$ & & 1.71 & 13.4 & -5 & $\begin{array}{r}127 \\
6\end{array}$ & $\underset{13}{222 \dagger}$ & $\begin{array}{l}2.98 \\
0.25\end{array}$ & $\begin{array}{l}4.26 \dagger \\
0.42\end{array}$ & $\begin{array}{l}2.33 \\
0.36\end{array}$ & $\begin{array}{l}1.92 \\
0.14\end{array}$ & $\begin{array}{r}39 \\
3\end{array}$ & $\begin{array}{r}49 \\
5\end{array}$ & $\begin{array}{r}76 \\
3\end{array}$ & ${ }_{2}^{87 \dagger}$ \\
\hline
\end{tabular}


TABLE I-Continued

\begin{tabular}{|c|c|c|c|c|c|c|c|c|c|c|c|c|c|c|c|}
\hline \multicolumn{2}{|c|}{$\begin{array}{c}\text { A-V } \\
\text { oxygen } \\
\text { difference }\end{array}$} & \multicolumn{2}{|c|}{$\begin{array}{l}\text { Right } \\
\text { atrial } \\
\text { pressure }\end{array}$} & \multicolumn{2}{|c|}{$\begin{array}{c}\text { Mean } \\
\text { pulmonary } \\
\text { artery } \\
\text { pressure }\end{array}$} & \multicolumn{4}{|c|}{ Brachial artery pressure } & \multicolumn{2}{|c|}{$\begin{array}{l}\text { Total } \\
\text { pulmonary } \\
\text { resistance }\end{array}$} & \multicolumn{2}{|c|}{$\begin{array}{c}\text { Total } \\
\text { systemic } \\
\text { resistance }\end{array}$} & \multicolumn{2}{|c|}{$\begin{array}{c}\text { Left } \\
\text { ventricular } \\
\text { work index }\end{array}$} \\
\hline $\mathbf{R}$ & $\mathbf{E}$ & $\mathbf{R}$ & $\mathrm{E}$ & $\mathbf{R}$ & $\mathbf{E}$ & S/D & $\mathbf{M}$ & S/D & $\mathbf{M}$ & $\mathbf{R}$ & $\mathbf{E}$ & $\mathbf{R}$ & $\mathbf{E}$ & $\mathbf{R}$ & $\mathbf{E}$ \\
\hline$m l . / 1 \mathrm{c}$ & $0 \mathrm{ml}$ & $m m$ & $\mathrm{Hg}$ & $m m$. & $\mathrm{Hg}$ & & & $\mathrm{Hg}$ & & $\begin{array}{r}\text { dyne } \\
\mathrm{cm}\end{array}$ & $\begin{array}{l}- \text { sec.- } \\
-5\end{array}$ & $\begin{array}{r}\text { dynes } \\
\mathrm{cm}\end{array}$ & -5 & Kg. $M$ & $\mid m i n .1$ \\
\hline 3.84 & 5.22 & 12 & 12 & 19 & & $117 / 70$ & 91 & $134 / 74$ & 98 & 191 & & 916 & 826 & 5.62 & 7.21 \\
\hline 3.23 & 4.65 & 5 & 7 & 23 & 24 & $133 / 64$ & 91 & $143 / 72$ & 103 & 280 & 237 & 1,190 & 1,018 & 6.44 & 8.98 \\
\hline 2.82 & 2.85 & 5 & 5 & 19 & & $126 / 69$ & 87 & $127 / 68$ & 89 & 140 & & 643 & 458 & 7.87 & 11.53 \\
\hline 3.08 & 5.00 & 4 & 5 & 17 & 25 & $125 / 72$ & 84 & $134 / 71$ & 88 & 134 & 145 & 661 & 512 & 7.16 & 10.19 \\
\hline 3.38 & 4.52 & 8 & 5 & 21 & 21 & $119 / 68$ & 84 & $129 / 72$ & 87 & 188 & 189 & 752 & 784 & 6.80 & 6.99 \\
\hline 3.80 & 4.30 & 10 & 14 & & & $112 / 72$ & 85 & $126 / 74$ & 91 & & & 520 & 508 & 6.41 & 9.90 \\
\hline 3.38 & 2.77 & & 1 & & & $114 / 59$ & 80 & $151 / 75$ & 112 & & & 493 & 422 & 8.11 & 18.76 \\
\hline 3.60 & 4.91 & 3 & 1 & 16 & 20 & $97 / 60$ & 73 & $137 / 80$ & 103 & 123 & 124 & 562 & 757 & 6.20 & 10.87 \\
\hline $\begin{array}{l}3.39 \\
0.12\end{array}$ & $\begin{array}{l}4.28 \dagger \\
0.34\end{array}$ & $\begin{array}{l}7 \\
1\end{array}$ & $\begin{array}{l}6 \\
2\end{array}$ & $\begin{array}{r}19 \\
1\end{array}$ & $\begin{array}{r}23 \\
1\end{array}$ & $\begin{array}{c}118 / 67 \\
4-4\end{array}$ & $\begin{array}{r}84 \\
2\end{array}$ & $\underset{5-3}{135 \dagger / 73 \dagger}$ & $\underset{3}{96 \ddagger}$ & $\begin{array}{r}184 \\
27\end{array}$ & $\begin{array}{r}183 \\
33\end{array}$ & $\begin{array}{r}717 \\
83\end{array}$ & $\begin{array}{c}660 \ddagger \\
76\end{array}$ & $\begin{array}{l}6.83 \\
0.30\end{array}$ & $\begin{array}{c}10.55 \ddagger \\
1.30\end{array}$ \\
\hline 5.66 & 6.34 & -3 & 1 & 12 & 12 & $154 / 72$ & 101 & $178 / 82$ & 158 & 191 & 101 & 1,608 & 1,334 & 4.02 & 11.75 \\
\hline 3.61 & 4.85 & 9 & 15 & 27 & 35 & $140 / 68$ & 100 & $166 / 92$ & 127 & 238 & 287 & 883 & 1,041 & 6.48 & 8.67 \\
\hline 6.44 & 8.49 & 11 & 13 & 29 & 42 & $167 / 104$ & 125 & $204 / 131$ & 155 & 469 & 524 & 2,022 & 1,459 & 7.14 & 10.29 \\
\hline 3.95 & 5.80 & 6 & 13 & & & $133 / 73$ & 99 & $160 / 89$ & 119 & & & 1,066 & 978 & 6.17 & 9.71 \\
\hline 4.04 & 4.88 & 2 & 4 & 20 & 23 & $104 / 64$ & 87 & $110 / 69$ & 86 & 208 & 144 & 907 & 540 & 6.01 & 9.86 \\
\hline 3.30 & 6.36 & & & $\begin{array}{r}\mathrm{RV} \\
34 / 0\end{array}$ & $\begin{array}{r}\mathrm{RV} \\
28 / 0\end{array}$ & $146 / 68$ & 112 & $187 / 72$ & 128 & & & 991 & 1,118 & 9.62 & 11.15 \\
\hline $\begin{array}{l}4.50 \\
0.50\end{array}$ & $\begin{array}{l}6.12 \dagger \\
0.55\end{array}$ & $\begin{array}{l}5 \\
3\end{array}$ & ${ }_{3}^{11 \dagger}$ & $\begin{array}{r}22 \\
4\end{array}$ & $\begin{array}{r}28 \\
7\end{array}$ & $\underset{9-6}{141 / 75}$ & $\begin{array}{r}104 \\
5\end{array}$ & $\begin{array}{c}168 \dagger / 89 \dagger \\
13-9\end{array}$ & $\underset{11}{129 \dagger}$ & $\begin{array}{r}277 \\
65\end{array}$ & $\begin{array}{r}264 \\
95\end{array}$ & $\begin{array}{r}1.246 \\
189\end{array}$ & $\begin{array}{r}1.078 \\
131\end{array}$ & $\begin{array}{l}6.57 \\
0.74\end{array}$ & $\begin{array}{c}10.24 \dagger \\
0.45\end{array}$ \\
\hline 5.83 & 7.16 & 2 & 4 & 12 & & $149 / 64$ & 95 & $162 / 70$ & 107 & 262 & & 2,070 & 2,030 & 5.26 & 6.21 \\
\hline 3.94 & 7.56 & 24 & 18 & 19 & 24 & $118 / 65$ & 87 & $135 / 70$ & 93 & 192 & 242 & 878 & 850 & 5.22 & 6.29 \\
\hline 6.81 & 7.14 & 13 & 18 & 39 & 53 & $169 / 75$ & 116 & $185 / 90$ & 126 & 571 & 699 & 1,698 & 1,662 & 3.52 & 4.32 \\
\hline 6.59 & 6.86 & 10 & & 25 & 33 & $122 / 63$ & 83 & $129 / 64$ & 83 & 516 & 555 & 1,714 & 1,396 & 3.25 & 4.21 \\
\hline $\begin{array}{l}5.79 \\
0.65\end{array}$ & $\begin{array}{l}7.18 \\
0.14\end{array}$ & $\begin{array}{r}12 \\
4\end{array}$ & $\begin{array}{r}13 \\
5\end{array}$ & $\begin{array}{r}24 \\
6\end{array}$ & $37 \ddagger$ & $\begin{array}{r}140 / 67 \\
12-3\end{array}$ & $\begin{array}{r}95 \\
7\end{array}$ & $\begin{array}{r}153+/ 74 \\
13-6\end{array}$ & $\begin{array}{r}102 \\
3\end{array}$ & $\begin{array}{r}385 \\
93\end{array}$ & $\begin{array}{l}499 \\
186\end{array}$ & $\begin{array}{r}1,590 \\
253\end{array}$ & $\begin{array}{r}1,484 \\
248\end{array}$ & $\begin{array}{l}4.31 \\
0.54\end{array}$ & $\begin{array}{l}5.26 \\
0.59\end{array}$ \\
\hline 2.01 & 3.85 & 18 & 26 & 35 & 39 & $134 / 52$ & 79 & & & 175 & 226 & 394 & & 8.87 & \\
\hline 2.42 & 3.73 & 7 & 7 & & & $165 / 91$ & 119 & $167 / 94$ & 121 & & & 737 & 941 & 13.73 & 11.04 \\
\hline 2.58 & 3.34 & 8 & 12 & & & $120 / 75$ & 95 & & & & & 386 & & 13.42 & \\
\hline $\begin{array}{l}2.33 \\
0.17\end{array}$ & $\begin{array}{l}3.64 \\
0.15\end{array}$ & $\begin{array}{r}11 \\
4\end{array}$ & $\begin{array}{r}15 \\
6\end{array}$ & & & $\begin{array}{r}140 / 73 \\
13-11\end{array}$ & $\begin{array}{l}98 \\
12\end{array}$ & & & & & $\begin{array}{l}506 \\
116\end{array}$ & & $\begin{array}{r}12.01 \\
1.55\end{array}$ & \\
\hline $\begin{array}{l}4.41 \\
0.23\end{array}$ & $\begin{array}{l}5.36 \\
0.14\end{array}$ & $\begin{array}{l}4 \\
1\end{array}$ & $\begin{array}{l}3 \\
1\end{array}$ & $\begin{array}{r}15 \\
5\end{array}$ & $\begin{array}{r}18 \\
6\end{array}$ & $\begin{array}{c}134 / 76 \\
8-3\end{array}$ & $\begin{array}{r}100 \\
5\end{array}$ & $\begin{array}{c}135 / 78 \\
8-4\end{array}$ & $\begin{array}{r}103 \\
2\end{array}$ & $\begin{array}{r}242 \\
30\end{array}$ & $\begin{array}{r}207 \\
35\end{array}$ & $\begin{array}{r}1,636 \\
118\end{array}$ & $\begin{array}{c}1,130 \dagger \\
123\end{array}$ & $\begin{array}{l}3.58 \\
0.33\end{array}$ & $\begin{array}{l}6.16 \\
0.81\end{array}$ \\
\hline
\end{tabular}


was treated and became euthyroid. Nine months later she was admitted for thyroidectomy and was asymptomatic. Examination revealed blood pressures ranging from $152 / 100$ to $170 / 110$ and evidence of hypertensive heart disease without congestive failure.

Basal metabolic rates of each patient are shown in Table I, with the first value being the lowest determination recorded in the two weeks prior to physiologic study and the second value being the measurement made at the time of study. The results of serum protein-bound iodine and/or thyroidal uptake of $\mathrm{I}^{131}$ determinations in these patients are indicated by an asterisk.

\section{METHODS}

The studies were performed in an air-conditioned room on patients in the postabsorptive state, usually after a sedative dose of sodium allyl barbiturate. Details of the methods used in this laboratory have been reported previously (6). Cardiac output was determined at rest and during the fourth minute of exercise performed supine on a stationary bicycle. Total systemic and pulmonary resistances were calculated as follows:

total systemic resistance (dynes-sec-cm. ${ }^{-5}$ )

and

$$
=\frac{\mathrm{BA}_{\mathrm{M}} \times 1,332}{\text { C.O. }}
$$

total pulmonary resistance (dynes-sec-cm. ${ }^{-5}$ )

$$
=\frac{P A_{M} \times 1,332}{C .0 .}
$$

where $\mathbf{B A}_{\mathbf{M}}=$ brachial arterial mean pressure $(\mathrm{mm} . \mathrm{Hg})$, $\mathrm{PA}_{\mathbf{M}}=$ pulmonary arterial mean pressure $(\mathrm{mm} . \mathrm{Hg})$ and C.O. = cardiac output (ml. per second). "Left ventricular work index" was approximated, in the absence of pulmonary capillary wedge pressures, by the calculation:

left ventricular work (Kg. M. per minute per M. $\left.{ }^{2}\right)$

$$
=\frac{\mathrm{CI} \times \mathrm{BA}_{\mathrm{M}} \times 1.36}{1,000} \text {. }
$$

\section{Results}

The data obtained in these patients are shown in Table I together with values obtained in healthy subjects studied in our laboratory with which they are compared.

\section{Group IA-Thyrotoxicosis without heart disease or congestive failure}

The mean cardiac output index of $5.98 \pm$ S.D. 0.89 L. per minute per $\mathrm{M}^{2}{ }^{2}$ in these eight patients was abnormally elevated $(p<0.001)$; the ratio of the cardiac index to the level of oxygen consumption index of $2.98 \pm$ S.D. 0.31 L. per $100 \mathrm{ml}$. was also significantly greater than in the healthy subjects $(p<0.01)$. During exercise the mean increase of the cardiac output was signifi- cant ( $<<0.02)$. In two patients (G. C., B. R.) a marked hyper-response of output during exercise was observed. In one patient (M. H.), whose metabolic rate at the time of study was considerably more elevated than on the ward, little further increase in oxygen consumption and no change in the cardiac output occurred during exercise.

The increased resting output in these patients was occasioned both by a greater stroke volume index $(p<0.02)$ and heart rate $(p<0.001)$ than normal. During exercise a significant increase in heart rate occurred and the stroke volume increased from 4 to $50 \mathrm{ml}$. per beat per $\mathrm{M} .^{2}$ in six of the eight patients; the mean increase was not significant. Atrial fibrillation was not observed.

The arteriovenous oxygen difference of $3.39 \pm$ S.D. $0.35 \mathrm{ml}$. per $100 \mathrm{ml}$. at rest was significantly lower than normal ( $p<0.01)$. During exercise, the mean arteriovenous oxygen difference widened normally; in the two patients in whom marked hyper-response of the cardiac output occurred, no change or actual decrease in oxygen extraction occurred. Arterial oxygen saturation was normal in each patient.

Mean right atrial and mean pulmonary arterial pressures for the group were high normal at rest and did not increase with exercise although a significant rise $(p<0.05)$ in pulmonary arterial systolic pressure occurred. Two patients (J. A., R. E.) had definite atrial hypertension at rest. Calculated total pulmonary resistances were low normal and did not change with exercise.

At rest total systemic resistance was lower than normal $(p<0.001)$. During exercise, despite a significant rise in systolic, diastolic and mean $(p<0.05)$ arterial pressures, a further significant decrease in systemic resistance occurred $(p<0.05)$. The left ventricular work index was greater than normal $(p<0.001)$ and increased significantly with exercise. The level of left ventricular work at rest in this group (6.83 \pm $0.85 \mathrm{Kg}$. M. per minute per M. ${ }^{2}$ ) equaled that of the normals during exercise $(6.16 \pm 1.99 \mathrm{Kg}$. $\mathrm{M}$. per minute per $\mathrm{M}^{2}$ ).

\section{Group IB-Thyrotoxicosis with antecedent heart disease but without congestive failure}

The resting mean cardiac index of $4.41 \pm$ S.D. $1.33 \mathrm{~L}$. per minute per $\mathrm{M}^{2}{ }^{2}$ in these pa- 
tients was greater than normal $(p<0.05)$ but the ratio of cardiac output to oxygen consumption did not differ from normal in contrast to Group IA. The exercise response of cardiac output for the group did not differ from normal or Group IA. The ratio of cardiac output to oxygen consumption was lower at rest $(p<0.05)$ and during exercise $(\mathrm{p}<0.05)$ than in Group IA. Two patients (J. J., F. S.) had relatively low outputs at rest. One (J. J.) was the only one in the group who had been digitalized; he showed a normal increase in output with exercise. The other patient, F. S., had a relatively low output during exercise as well, despite the expected increase in oxygen consumption. He was the only patient in this group who presented atrial fibrillation at the time of study. Another patient, M. He., failed to show an increase in output with exercise despite a marked increase in oxygen consumption; she subsequently developed congestive failure (vide infra, Group IIA). The mean stroke volume index for the group was not significantly elevated at rest nor did it increase with exercise. The mean heart rate was elevated at rest $(p<0.05)$ and increased with exercise. In addition to the one patient with atrial fibrillation at the time of study three other patients (J. J., M. R., L. P.) had transient fibrillation during hospitalization prior to study. The mean arteriovenous oxygen difference was greater than in Group IA ( $p<$ 0.05 ) and did not differ from normal. With exercise it increased considerably to a high normal level which was greater than in Group IA ( $p<$ 0.02). Mean right atrial pressure at rest was normal but increased significantly during exercise in contrast to Group IA. Patient F. S. had atrial hypertension. Mean pulmonary arterial pressure was in the high normal range at rest and during exercise. Slight pulmonary hypertension developed during exercise in the patient with atrial fibrillation (F. S). With one exception (L. P.) the mean brachial artery pressure both at rest and during exercise was higher in each patient in this group than in any patient in Group IA, which was expected since four of the six had hypertensive heart disease. Mean brachial artery pressure for the group was not higher than in the normal subjects, however, and systemic resistance at the time of study was in the normal range. With exercise mean brachial artery pressure rose and systemic resistance did not change. Pulmonary resistance did not differ from normal. The left ventricular work index was elevated at rest $(\mathrm{p}<0.01)$ and rose with exercise.

\section{Thyrotoxicosis complicated by congestive failure}

Group IIA. In these four patients the mean cardiac index at rest was not different from normal. During exercise no significant change in output occurred in contrast to normal subjects. The ratio of cardiac output to oxygen consumption at rest and during exercise was lower in each patient than in any patient in Group IA. The absolute level of cardiac index during exercise for this small group was lower than normal ( $\mathrm{p}<$ $0.05)$. The stroke volume index was in the normal range and did not increase during exercise. The heart rate was elevated at rest and increased in three of the four during exercise. The mean arteriovenous oxygen difference for the group was abnormally widened at rest and exercise when compared with normal ( $\mathrm{p}<0.05)$. Mean atrial pressure was elevated at rest and exercise compared with normals $(p<0.02)$. Patient M. He., who was not clinically in failure at the time of study, had a normal atrial pressure. A significant pulmonary hypertension ( $p<0.02$ ) occurred with exercise. Pulmonary resistance was high normal at rest and exercise. Although a significant increase in left ventricular work occurred with exercise, the absolute level during exercise was not different from that in Group IA or IB at rest.

Group IIB. The hemodynamic data obtained in these three patients differed strikingly from the other patients studied. The mean cardiac index of $8.93 \pm$ S.D. 0.97 L. per minute per M. ${ }^{2}$ calculated for this small group was higher than in the normals $(p<0.001)$, Group IA $(p<0.001)$ or in Group IIA $(p<0.001)$, and the mean ratio of cardiac output to oxygen consumption was significantly greater than in Group IA $(p<0.001)$. With exercise a marked drop in cardiac index occurred in each patient in this group in contrast to all of the other patients. The mean stroke index for the group was higher than normal $(p<$ 0.01 ) and decreased with exercise. The mean heart rate for the group was elevated at rest $(p<$ 
0.001 ) and increased in each during exercise; two of these three patients had atrial fibrillation. The mean arteriovenous difference for the group was quite narrowed both at rest and exercise ( $p<$ 0.01). Mean atrial pressures were elevated at rest and became yet more elevated during exercise in two of the three; normal values were obtained in P. R. who was not in failure clinically at the time of study. Pulmonary arterial pressure was elevated in the one patient in whom it was measured. Systemic resistance was markedly reduced in each patient and left ventricular work was increased at rest to a level higher than the exercise level in all but one (B. R.) of the patients in the entire series.

\section{Discussion}

The circulatory responses to thyrotoxicosis observed in the seven patients without heart disease or congestive failure (Group IA) at rest were, in general, similar to those described by others (7-16). The responses of the cardiac output and systemic resistance to mild exercise in these patients were qualitatively similar to healthy persons and the increased blood flow associated with thyrotoxicosis both at rest and during exercise occurred without significant change in right atrial or pulmonary arterial pressures. These data strongly suggest myocardial competence and have been used as a basis for comparison with the other groups.

Since hyperthyroid patients both without congestive failure (Group IA) and some of those with congestive failure (Group IIB) had narrowed arteriovenous differences and thus greater than normal ratios of cardiac output to oxygen consumption, the commonly used relationship of cardiac output to oxygen consumption as a measure of cardiac competence was not possible. Although any of these hyperthyroid individuals might not have been basal at the time of the "rest" study and hence factors tending to elevate the cardiac output out of proportion to oxygen requirement might have been operative, the operation of such factors was largely overcome by the exogenous load of exercise. The exercise cardiac output and arteriovenous difference data clearly separate the four groups of patients and the arteriovenous difference remained less than the normal during exercise in the second group of patients who had had congestive failure (Group
IIB) as well as in the patients without failure (Group IA). We assume, therefore, that regardless of the absolute level of cardiac output its change with exercise was the best indicator of cardiac competence for the evaluation of these patients.

The patients in Group IB were initially classified as not having myocardial inadequacy despite the presence of heart disease because of the absence of congestive failure. This clinical impression was confirmed by the qualitatively normal cardiac output response to exercise. Although the cardiac output was elevated in this group with respect to normal, the ratio of the cardiac output to the level of oxygen consumption was less than in the thyrotoxic patients without heart disease. More elaborate measurements of oxygen demand and output response relationship (17) in patients of this kind would be of particular interest, since the significant rise in atrial pressure during exercise in this group also suggests some degree of impairment in myocardial function.

The physiologic data in the patients who had had clinical congestive failure differed markedly from those obtained in the patients without failure. In four of the patients (Group IIA) the cardiac output was in the normal range at rest but was quite inadequate with respect to the elevated oxygen consumption as reflected in the low ratio of cardiac output to oxygen consumption and the widened arteriovenous oxygen difference. This group therefore presented relatively "low output" failure when compared with the patients with thyrotoxicosis without congestive failure (Group IA). When compared with seven euthyroid patients with congestive failure on the basis of primary myocardial disease (6) in whom the cardiac output averaged $1.93 \pm$ S.D. 0.31 L. per minute per $\mathrm{M.}^{2}$, however, these patients had relatively "high output" failure. The elevation of right atrial pressure at rest and of atrial and pulmonary arterial pressure during exercise and the failure of the cardiac output to rise or of systemic resistance to decrease with exercise found in this group were entirely similar to the findings in euthyroid patients with heart failure due to myocardial disease. Three of the four patients in this group had definite heart disease antedating the onset of thyrotoxicosis.

The findings in the fourth patient, S. S., are of 
particular interest. At the time of study, despite his young age and lack of definitive evidence of rheumatic heart disease, he was considered as probably having heart disease antedating his thyrotoxicosis on the basis of the clinical and hemodynamic data. Over the course of the two years following study as he returned to full health and eventually had an entirely normal exercise tolerance and cardiovascular examination, our original impression became untenable and he was categorized as a patient in whom the hyperthyroid state had transiently produced myocardial inadequacy and congestive heart failure.

In the other group of patients who had presented congestive failure clinically (Group IIB) the decrease in cardiac output with exercise in the presence of elevation of the right atrial pressure in two of the three and of pulmonary arterial pressure in the one in whom these data were obtained were also similar to euthyroid patients with congestive failure. The striking finding in each of these patients, however, was a cardiac output and cardiac output to oxygen consumption ratio which was not only considerably greater than normal but also greater than in any patient with thyrotoxicosis not in failure (Group IA). The first of these patients had a moderate anemia in addition to hyperthyroidism at the time of study which contributed to his circulatory load. We have found, however, that a considerable hyperresponse of cardiac output characteristically occurs during exercise in patients with hemoglobins of $8 \mathrm{Gm}$. (18) in contrast to the fall in cardiac output observed in this patient. $\mathrm{He}$ has since totally recovered, and resembles the young patient described in 1929 by Burwell, Smith and Neighbors (19) who presented a combination of thyrotoxicosis and pernicious anemia, in whom the cardiac output was far above that expected on the basis of metabolic demand, and who also apparently had no antecedent or residual heart disease after treatment of his anemia and thyrotoxicosis. The second patient in this group was older, had a questionable history of angina pectoris, had had severe cardiac irritability with runs of ventricular tachycardia on entry and remained in clinical congestive failure for nine months until she became euthyroid following thyroidectomy, at which time she presented no signs of heart disease. The third patient had mild hypertensive heart disease without clinically apparent decrease in myocardial reserve until the development of hyperthyroidism and subsequent congestive failure. Thus, in two of these three patients no antecedent or residual heart disease was evident; in the third, only mild hypertensive heart disease was present before and after thyrotoxicosis.

Elucidation of the genesis of the clinical syndrome of congestive failure in these patients requires a consideration of the cardiovascular stresses imposed by thyrotoxicosis and the mechanisms by which they may cause myocardial incompetence.

Despite the absence of characteristic cardiac morphologic abnormalities in patients who have succumbed with thyrotoxicosis and heart failure $(5,20,21)$, a direct alteration of myocardial function by thyroxin has been demonstrated in both clinical and experimental hyperthyroidism (15, 22-30). Impairment of myocardial energy production due to altered enzyme function may have been a factor involved in the failure of an adequate cardiac output response to exercise(31-35). The action of thyroxin on myocardial function may well be mediated by sensitization of the myocardium to sympathetic nerve stimulation and to sympathomimetic amines (36-40). An increased concentration of catechol amines has also been demonstrated in the myocardia of thyrotoxic dogs (41). The hyper-response of cardiac output to exercise (G. C., B. R.) and the occurrence of paroxysmal ventricular tachycardia in Patient P. R. may well be attributable to this phenomenon $(42,43)$. Furthermore the possibility that myocardial hypoxia and hence impaired function may be caused by excessive catechol amine concentrations has also been mentioned (41).

In addition to a possible direct impairment of myocardial metabolism, thyrotoxicosis frequently is associated with the occurrence of atrial fibrillation which was present in five of the seven patients with congestive failure in the present study. Data from several studies $(3,44,45)$ have suggested that the occurrence of this arrhythmia is related to the age of the patient with thyrotoxicosis and hence with the possibility of antecedent or underlying heart disease. The absence of this arrhythmia in the patients without heart disease or congestive failure (Group IA) and its occurrence in four of the six patients with heart dis- 
ease but without congestive failure (Group IB) are consonant with this view. The occurrence of atrial fibrillation in the two younger patients (S. S., G. F.) who recovered from congestive failure and from the arrhythmia without evidence of heart disease, however, suggests thyrotoxicosis as the immediate cause perhaps because of increased myocardial sensitivity to epinephrine (39). The persistence of the arrhythmia in these two patients for over two years after they had become euthyroid and its eventual subsequent disappearance in one (S. S.) suggests, however, a disorder of a more chronic nature. Althought atrial fibrillation does not compromise the circulation at rest, impaired circulatory responses to the increased circulatory demands of exercise are well-documented $(46-47)$. Since the circulation of the hyperthyroid patient is under a constantly increased load even at rest, the probable importance of this arrhythmia as a factor in the development of congestive failure is evident (48-49).

In addition to the direct alteration of myocardial function in the presence of excess thyroxin, the probable operation of a considerably increased peripheral circulatory load in these patients is suggested by the occurrence of heart failure at absolute levels of cardiac output which were normal or high. The "normal" cardiac outputs of the patients with antecedent heart disease (Group IIB; M. He., N. S., H. K.) and of Patient S. S. (Group IIB) who apparently had no antecedent or residual heart disease were inadequate with respect to the increased oxygen requirement of thyrotoxicosis; the ratio of cardiac output to oxygen consumption was abnormally low and the arteriovenous oxygen difference abnormally widened. The cardiac outputs of the other three patients (Group IIB) at rest, however, were more than adequate with respect to this usual measure of circulatory load since the ratio of cardiac output to oxygen consumption was increased and the arteriovenous oxygen difference abnormally narrowed. Since clinical congestive failure had occurred and the hemodynamic responses observed in these individuals during exercise were compatible with myocardial inadequacy, an additional peripheral nonoxygen load may be postulated for which their cardiac outputs were inadequate. The existence of a nonoxygen circulatory load $(10,19,50,51)$ in un- complicated thyrotoxicosis is also suggested by the elevation of the ratio of cardiac output to oxygen consumption and narrowed arteriovenous difference found in the patients without heart disease or congestive failure (Group IA).

The nature of a peripheral nonoxygen circulatory load remains speculative. The evidence is excellent that many of the cardiovascular phenomena associated with excess thyroxin may be due in considerable part to hyper-reactivity to catechol amines and peripheral sympathomimetic hypersensitivity (52). It is difficult, however, to attribute the warm, flushed skin and decrease in total systemic resistance found in many thyrotoxic patients solely to chronically increased sympathetic stimulation or reactivity.

The peripheral circulatory stigmata of thyrotoxicosis in man, in contrast to dogs, whose chief avenue of heat loss is through the lungs, have suggested that a considerable nonoxygen load in this disorder may be attributable to an abnormally increased skin and peripheral blood flow caused in part by increased heat loss requirements (5357). The hemodynamic data in these thyrotoxic patients resemble in many important respects the data obtained in patients with systemic arteriovenous fistulae studied in our laboratory (58). In these patients, in whom the circulatory load is obviously restricted to the low resistance lesion in the peripheral circulation, an abnormally high ratio of cardiac output to oxygen consumption and narrowed arteriovenous difference were found both in patients with and those without congestive heart failure and the changes observed in cardiac output and intravascular pressures during exercise were similar to the corresponding groups in the present study.

Other compensatory consequences of systemic arteriovenous fistulae and of thyrotoxicosis are also similar. An increase in blood volume frequently occurs in thyrotoxicosis and is commonly found in patients with arteriovenous fistulae (58$61)$. In both of these conditions edema may occur and indeed simulate congestive failure $(62,63)$ in the presence of quite normal hemodynamic responses to exercise. Edema and a 35 per cent increase in blood volume were found despite an adequate cardiac output response to exercise and normal atrial pressure in Patient L. P. (Group IB) who had rheumatic heart disease and had 
transient bouts of atrial fibrillation. The continued development of hypervolemia, which initially represents a desirable circulatory adjustment, may well be a factor in the development of myocardial inadequacy (64) because of an augmented venous return, overdistention of the heart, and perhaps by contributing to the development of atrial fibrillation. Since the finding of an inadequate cardiac output response to exercise in the patients in Group IIB clearly indicates that actual myocardial inadequacy may develop in patients with thyrotoxicosis, as in patients with systemic arteriovenous fistulae, at remarkably high absolute levels of cardiac output, it is evident that the term "noncardiac circulatory congestion simulating congestive failure" (62) may not characterize adequately the abnormalities of the circulation in patients with these disorders.

The data in this report suggest that congestive heart failure may occur in the course of thyrotoxicosis by several mechanisms. Inadequate myocardial function with respect to the increased circulatory load may result from a direct effect of thyroxin on the heart in the presence of sympathomimetic amines, the increased circulatory load of the disease may overcome a myocardium damaged by heart disease of other etiology and the increased circulatory load of thyrotoxicosis may of itself overcome the myocardial reserve of the apparently normal heart. When a decrease in myocardial reserve is the major factor the cardiac output tends to be in the "normal" range. When the decrease in myocardial reserve is less and the increase in circulatory load greater the cardiac output may be remarkably high.

\section{SumMaRY}

1. Clinical and hemodynamic studies are reported in 20 patients with thyrotoxicosis, in seven of whom congestive failure had occurred.

2. In 14 patients without congestive failure the hemodynamic responses during exercise were qualitatively normal, despite the fact that six had antecedent heart disease.

3. In the patients who had been in congestive failure the absolute level of cardiac output was normal in four and was markedly elevated in three. All had inadequate responses of the cardiac output to exercise.
4. Atrial fibrillation occurred only in patients in congestive failure or in those with antecedent heart disease.

5. The peripheral circulatory load in thyrotoxicosis is hemodynamically similar to that of systemic arteriovenous fistulae.

6. Congestive failure occurred in the presence of the circulatory load of thyrotoxicosis when myocardial function was reduced by heart disease of other etiology, when thyrotoxicosis transiently caused an inadequate myocardial function, or when the circulatory load apparently overcame the reserve of even the otherwise normal heart.

\section{REFERENCES}

1. Maher, C. C., and Sittler, W. W. The cardiovascular state in thyrotoxicosis. J. Amer. med. Ass. 1936, 106, 1546.

2. Lerman, J., and Means, J. H. Cardiovascular symptomatology in exophthalmic goiter. Amer. Heart J. 1932, 8, 55.

3. Ernstene, A. C. The cardiovascular complications of hyperthyroidism. Amer. J. med. Sci. 1938, 195, 248.

4. Levine, S. A., and Walker, G. L. Further observations on latent hyperthyroidism masked as heart disease: Angina pectoris. New Engl. J. Med. 1929, 201, 1021.

5. Friedberg, C. K. Diseases of the Heart, 2nd ed. Phildelphia, W. B. Saunders Company, 1956, p. 1000 .

6. Graettinger, J. S., Muenster, J. J., Checchia, C. S., Grissom, R. L., and Campbell, J. A. A correlation of clinical and hemodynamic studies in patients with hypothyroidism. J. clin. Invest. 1958, $37,502$.

7. Liljestrand, G., and Stenström, N. Clinical studies on the work of the heart during rest. I. Blood flow and blood pressure in exophthalmic goiter. Acta med. scand. 1925, 63, 99.

8. Fullerton, C. W., and Harrop, G. A., Jr. The cardiac output in hyperthyroidism. Bull. Johns Hopk. Hosp. 1930, 46, 203.

9. Blumgart, H. L., Gargill, S. L., and Gilligan, D. R. Studies on the velocity of blood flow. XIII. The circulatory response to thyrotoxicosis. J. clin. Invest. 1930, 9, 69.

10. Boothby, W. M., and Rynearson, E. H. Increase in circulation rate produced by exophthalmic goiter compared with that produced in normal subjects by work. Arch. intern. Med. 1935, 55, 547.

11. Myers, J. D., Brannon, E. S., and Holland, B. C. A correlative study of the cardiac output and the hepatic circulation in hyperthyroidism. J. clin. Invest. 1950, 29, 1069. 
12. Talmers, F. N., Regan, T. J., DeFazio, V., Leight, L., and Hellems, H. K. The effects of hyperthyroidism on the circulatory system. Clin. Res. Proc. 1955, 3, 120.

13. Leight, L., DeFazio, V., Talmers, F. N., Regan, T. J., and Hellems, H. K. Coronary blood flow, myocardial oxygen consumption, and myocardial metabolism in normal and hyperthyroid human subjects. Circulation 1956, 14, 90.

14. Sensenbach, W., Madison, L., Eisenberg, S., and Ochs, L. The cerebral circulation and metabolism in hyperthyroidism and myxedema. J. clin. Invest. 1954, 33, 1434.

15. Rowe, G. G., Huston, J. H., Weinstein, A. B., Tuchman, H., Brown, J. F., and Crumptom, C. W. The hemodynamics of thyrotoxicosis in man with special reference to coronary blood flow and myocardial oxygen metabolism. J. clin. Invest. 1956, 35, 272.

16. Humerfelt, S., Muller, O., and Storstein, O. The circulation in hyperthyroidism: A cardiac catheterization study before and after treatment. Amer. Heart J. 1958, 56, 87.

17. Huckabee, W. E. The role of anaerobic metabolism in the performance of mild muscular work. II. The effect of asymptomatic heart disease. J. clin. Invest. 1958, 37, 1593.

18. Campbell, J. A., and Graettinger, J. S. The effect of exercise on the hemodynamics in patients with chronic anemia. In press.

19. Burwell, C. S., Smith, W. C., and Neighbors, D. The output of the heart in thyrotoxicosis, with the report of a case of thyrotoxicosis combined with primary pernicious anemia. Amer. J. med. Sci. 1929, 178, 157.

20. McEachern, D., and Rake, G. A study of the morbid anatomy of hearts from patients dying with hyperthyroidism. Bull. Johns Hopk. Hosp. 1931, 48, 273.

21. Weller, C. V., Wanstrom, R. C., Gordon, H., and Bugher, J. C. Cardiac histopathology in thyroid disease. Amer. Heart J. 1932, 8, 8.

22. Aub, J. C., and Stern, N. S. The influence of large doses of thyroid extracts on the total metabolism and heart in a case of heart-block. Arch. intern. Med. 1918, 21, 130.

23. Priestley, J. T., Markowitz, J., and Mann, F. C. The tachycardia of experimental hyperthyroidism. Amer. J. Physiol. 1931, 98, 357.

24. McEachern, D. Direct measurements of oxygen consumption of isolated, beating auricles from normal and thyrotoxic guinea-pigs. Bull. Johns Hopk. Hosp. 1932, 50, 287.

25. Davis, J. E., and Hastings, A. B. The effect of thyroxin on the tissue metabolism of excised limulus heart. Amer. J. Physiol. 1936, 114, 618.

26. Shelley, W. B., Code, C. F., and Visscher, M. B. Influence of thyroid, dinitrophenol and swimming on glycogen and phosphocreatine level of the rat heart in relation to cardiac hypertrophy. Amer. J. Physiol. 1943, 138, 652.

27. Gordon, E. S., and Heming, A. E. Effect of thyroid treatment on the respiration of various rat tissues. Endocrinology 1944, 34, 353.

28. Leblond, C. P., and Hoff, H. E. Comparison of cardiac and metabolic actions of thyroxine, thyroxine derivatives and dinitrophenol in thyroidectomized rats. Amer. J. Physiol. 1944, 141, 32.

29. Moses, L. E. Mechanism of effect of hyperthyroidism on cardiac glycogen. Amer. J. Physiol. 1944, 142, 686.

30. Ullrick, W. C., and Whitehorn, W. V. Influence of thyroid hormone on respiration of cardiac tissue. Amer. J. Physiol. 1952, 171, 407.

31. Means, J. H., Hertz, S., and Lerman, J. Nutritional factors in Graves' disease. Ann. intern. Med. 1937, 11, 429.

32. Williams, R. H., Egana, E., Robinson, P., Asper, S. P., and Dutoit, C. Alterations in biologic oxidation in thyrotoxicosis. I. Thiamine metabolism. Arch. intern. Med. 1943, 72, 353.

33. Ershoff, B. H., and Hershberg, D. The beneficial effects of yeast on the cardiac failure of hyperthyroid rats. Amer. J. Physiol. 1945, 145, 16.

34. Lardy, H. A., and Feldott, G. Metabolic effects of thyroxine in vitro. Ann. N. Y. Acad. Sci. 1951, 54, 636.

35. Martius, C., and Hess, B. Mode of action of thyroxine. Arch. Biochem. 1951, 33, 486.

36. Sawyer, M. E. M., and Brown, M. G. The effect of thyroidectomy and thyroxine on the response of the denervated heart to injected and secreted adrenine. Amer. J. Physiol. 1935, 110, 620.

37. Wise, B., and Hoff, H. E. The effect of the autonomic hormones on the thyrotoxic heart. J. Pharmacol. exp. Ther. 1938, 64, 217.

38. Raab, W. Diminution of epinephrine sensitivity of the normal human heart through thiouracil. J. Lab. clin. Med. 1945, 30, 774.

39. Hoffmann, F., Hoffmann, E. J., and Talesnik, J. Influence of the thyroid hormone on the effector systems of the mammalian heart. Amer. J. Physiol. 1947, 148, 689.

40. Horstmann, P. The effect of adrenaline on the oxygen consumption in diabetes mellitus and in hyperthyroidism. Acta Endocr. (Kbh.) 1954, 16, 233.

41. Raab, W. Adreno-sympathogenic heart disease (neurohormonal factors in pathogenesis and treatment). Ann. intern. Med. 1948, 28, 1010.

42. McMichael, J., and Sharpey-Schafer, E. P. Cardiac output in man by a direct Fick method. Brit. Heart J. 1944, 6, 33.

43. Bishop, J. M., Donald, K. W., and Wade, O. L. Circulatory dynamics at rest and on exercise in the hyperkinetic states. Clin. Sci. 1955, 14, 329.

44. Bortin, M. M., Silver, S., and Yohalem, S. B. Diagnosis of masked hyperthyroidism in cardiac patients with auricular fibrillation. Amer. J. Med. 1951, 11, 40 . 
45. Engstrom, W. W., Berteau, B. A., and Engbring, N. H. Cardiac complications in patients with nontoxic and toxic nodular goiter and with Graves' disease (abstract). J. Lab. clin. Med. 1956, 48, 804.

46. Blumgart, $H$. The reaction to exercise of the heart affected by auricular fibrillation. Heart 1924, 11, 49.

47. Broch, O. J., and Müller, O. Haemodynamic studies during auricular fibrillation and after restoration of sinus rhythm. Brit. Heart J. 1957, 19, 222.

49. Barker, P. S., Bohning, A. L., and Wilson, F. N. Auricular fibrillation in Graves' disease. Amer. Heart J. 1932, 8, 121.

49. Ernstene, A. C. The use of digitalis and quinidine sulfate in hyperthyroidism. Surg. Clin. N. Amer. 1941, 21, 1365.

50. Robinson, G. C. The measurement of cardiac output in man and its variations. J. Amer. med. Ass. 1926, 87, 314.

51. Blalock, A., and Harrison, T. R. The effects of thyroidectomy and thyroid feeding on the cardiac output. Surg. Gynec. Obstet. 1927, 44, 617.

52. Brewster, W. R., Jr., Isaacs, J. P., Osgood, P. F., and King, T. L. The hemodynamic and metabolic interrelationships in the activity of epinephrine, norepinephrine and the thyroid hormones. Circulation 1956, 13, 1.

53. Roberts, E., and Griffith, J. Q., Jr. A quantitative study of cutaneous capillaries in hyperthyroidism. Amer. Heart J. 1937, 14, 598.

54. Stewart, H. J., and Evans, W. F. The peripheral blood flow in hyperthyroidism (abstract). J. clin. Invest. 1940, 19, 779.
55. Eichna, L. W., and Wilkins, R. W. Blood flow to the forearm and calf. IV. Thyroid activity: Observations on the relation of blood flow to basal metabolic rate. Bull. Johns Hopk. Hosp. 1941, 68, 512.

56. Abramson, D. I., and Fierst, S. M. Resting peripheral blood flow in the hyperthyroid state. Arch. intern. Med. 1942, 69, 409.

57. Morris, L. E., and Blumgart, H. L. Velocity of blood flow in health and disease. Circulation 1957, $15,448$.

58. Muenster, J. J., Graettinger, J. S., and Campbell, J. A. A correlation of clinical and hemodynamic studies in patients with systemic arteriovenous fistulae. Circulation. In press.

59. Holman, E. Experimental studies in arteriovenous fistulas. I. Blood volume variations. Arch. Surg. 1924, 9, 822.

60. Chang, H. C. The blood volume in hyperthyroidism. J. clin. Invest. 1931, 10, 475.

61. Gibson, J. G., 2nd, and Harris, A. W. Clinical studies of the blood volume. V. Hyperthyroidism and myxedema. J. clin. Invest. 1939, 18, 59.

62. Eichna, L. W., Farber, S. J., Berger, A. R., Rader, B., Smith, W. W., and Albert, R. E. Non-cardiac circulatory congestion simulating congestive heart failure. Trans. Ass. Amer. Phycns 1954, 67, 72.

63. Youmans, W. B., and Huckins, A. R. Hemodynamics in Failure of the Circulation. Springfield, Ill., Charles C Thomas, 1951.

64. Stead, E. A., Jr. Role of cardiac output in mechanisms of congestive heart failure. Amer. J. Med. 1949, 6, 232. 